\title{
ELECTRON MICROSCOPY OF WOOD OF CALLIXYLON AND CORDAITES ${ }^{1}$
}

\author{
Rudolf Schmid \\ Department of Botany, University of Michigan, Ann Arbor
}

$\begin{array}{lllllllll}\text { A } & B & S & T & R & A & C & T\end{array}$

\begin{abstract}
Replicas and ultrathin sections of the wood of two Paleozoic genera, Callixylon and Cordaites, were examined with the electron microscope. The pattern of wall layering of Callixylon closely resembles that of extant plants. An electron-dense compound middle lamella markedly thickened at the corners of cells, a thin, electron-transparent $S_{1}$ layer of the secondary wall, and a thick, electron-dense, partially decayed $S_{2}$ layer of the secondary wall are evident in transverse sections of tracheids. No $S_{3}$ layer seems to be present. The structure of the bordered pit-pairs of Callixylon is described in detail. The slitlike outer pit apertures are conspicuously narrower and shorter than the inner pit apertures. Both sections and replicas of the bordered pit-pairs display pit membranes lacking tori. Microfibrillar structure is obscure in both sections and replicas of Callixylon wood. Replicas of the bordered pits of Cordaites wood are very similar to those of Callixylon. Pit membranes lack tori, and microfibrillar structure is not very discernible. Knowledge about the evolution of the torus is summarized. It is postulated that the type of pit membrane of Callixylon and Cordaites, which is very homogeneous in structure and lacks a torus, represents a primitive condition among gymnosperms from which structurally more complex pit membranes and the torus later evolved.
\end{abstract}

Although electron microscopic investigations of living material are now legion, ultrastructural studies of fossilized material have been relatively few. Perhaps the first such study was that of Preston and Cuckow (1944) on coal. Investigation of the ultrastructure of coal remains an active field of research today (references can be found in Sen's 1963 review). In recent years many workers have extensively pursued the electron microscopy of Precambrian and Carboniferous microorganisms (see Barghoorn and Schopf, 1966), but microfossils were detected with the electron microscope as long ago as 1948 (Barton and Jones). Electron microscopy of fossilized material of the higher plants, however, has remained a rather neglected field. The first electron microscopic work on fossilized vascular plants was published in 1951 by Wesley and Kuyper and dealt with the xylem elements of Lepidodendron. Fry (1954) later did similar work on the lycopod Paurodendron. Eicke (1952, 1953, 1954, 1957) found ultrastructural details of the silicified wood of Glyptostroboxylon to be very similar to those of recent

${ }^{1}$ Received for publication 30 July 1966.

This work was supported by a University of Michigan Rackham Predoctoral Fellowship and a National Science Foundation Summer Fellowship for Graduate Teaching Assistants to the author, and by NSF grant GB-3038 to Professor C. B. Beck.

The author is greatly indebted to Professor Beck for assistance during the course of the investigation and with the preparation of the manuscript, to Professor C. A. Arnold for supplying fossil material, to Professors W. C. Bigelow and R. J. Lowry for guidance in the techniques of electron microscopy, and to Mr. R. M. Tetley for many helpful comments. woods, and on the basis of these studies has postulated about the probable nature of silicification. More recently, Purelis (1962) compared the fine structure of the cell walls of the fossil fern Psaronius and the living fern Botrychium. Spores, pollen, and other microfossils have also been examined with the electron microscope (Ehrlich and Hall, 1959; Jux and Moericke, 1965; Pettitt, 1966; Pettitt and Chaloner, 1964).

Various replication techniques have generally been used in electron microscopic studies of fossilized material. Ultrathin sectioning technique has been employed with some success in the study of microfossils (Ehrlich and Hall, 1959; Jux and Moericke, 1965; Pettitt, 1966; Pettitt and Chaloner, 1964) and coal (McCartney, Walline, and Ergun, 1961), but it has not been used to advantage in studies of fossilized wood. Although replication techniques are indispensable in investigations of fossilized material, it seemed reasonable that ultrathin sections might provide valuable information about features perhaps not illustrated, or not so readily illustrated, by replication techniques. Consequently, both replication technique and ultrathin sectioning technique were used to prepare some unusually well-preserved wood of Callixylon, an Upper Devonian and Lower Mississippian plant, for electron microscopic examination. The electron microscope was also used to examine replicas of other fossil woods, especially Cordaites.

Materials AND METHODs-Replication technique was used to examine silicified wood of 
Callixylon newberryi (Dawson) Elkins and Wieland, a plant from the New Albany Shale (Upper; Devonian) of Indiana that was previously studied with the light microscope (Arnold, 1931). Two-stage positive replicas were prepared by applying cellulose acetate film (obtainable from Electron Optics Division of $\mathrm{JEOL}^{2}$ under the trade name of Bioden R. F. A. Replica Film) to acetone-soaked, newly fractured radial surfaces of the wood. Replicas of transverse and tangential surfaces were not very successful and yielded no information. When dry, the Bioden film was peeled from the specimen, shadowed with chromium at an angle of $45 \mathrm{deg}$ in a vacuum evaporator, and then coated with a layer of carbon evaporated at $90 \mathrm{deg}$ from the horizontal. The Bioden-chromium-carbon sandwiches were cut into small squares that were attached, carboncoated side down, to 100 -mesh copper grids soaked with molten paraffin. The Bioden and paraffin were then dissolved in acetone and carbon tetrachloride, respectively, in a Soxhlet extractor (Beals and Bigelow, 1962) for about $1 \mathrm{hr}$ for each solvent. Preliminary light microscopic inspection of the replicas and final light microscopic inspection of the prepared grids saved considerable time by enabling the investigator to select the most promising areas of the replicas for study. Elaborations of this technique are in Côté, Koran, and Day (1964).

Replicas were also prepared of calcified wood of a species of Cordaites that was cut radially with a diamond saw before being replicated. Professor C. A. Arnold (personal communication, 1966) tentatively identified this specimen from What Cheer of the Des Moines Series (Pennsylvanian) of Iowa as the Cordaites iowensis of Wilson and Johnston (1940), collected from the same locality. ${ }^{3}$

Ultrathin sections were made of non-mineralized wood of an undetermined species of Callixylon from the Berea sandstone in the Kinderhookian Series (Lower Mississippian) of Ohio. The wood was saturated with propylene oxide prior to infiltration with an epoxy resin mixture (A. R. Spurr, 1961. Refinements in the epoxy embedding technique. Unpublished information sheet.). Ultrathin sections (considerably less than $90 \mathrm{~m} \mu$ thick) of the polymerized epon blocks were cut with glass knives on a Sorvall PorterBlum ultramicrotome. Attempts to prepare ultrathin sections of desilicified wood of Callixylon newberryi for ultrastructural examination were not successful, but electron microscopy of sections of desilicified material has proven of

\footnotetext{
2 JEOLCO (USA), Inc., 477 Riverside Ave., Medford, Mass. 02155.

${ }^{3}$ Arnold (personal communication) applies the name Dadoxylon to this material and in general to cordaitean secondary wood. He prefers to restrict the use of Cordaites to leaf material since this name was first applied to leaves and since wood named as Cordaites might actually belong to other plants.
}

value in other cases (unpublished work on Prototaxites; Ehrlich and Hall, 1959; Pettitt, 1966).

An RCA EML-1A electron microscope and a Jem-6A electron microscope, operated at 50 or $80 \mathrm{kv}$, were used for examination and micrography of the replicas and sections.

Large pieces of the non-mineralized wood of Callixylon were embedded in celloidin (Sass, 1958). Celloidin sections cut at 10 to $20 \mu$ on a sliding microtome and epoxy resin sections cut several microns thick on the ultramicrotome were examined with a light microscope for purposes of orientation.

Results-The badly distorted nature of the non-mineralized wood of Callixylon is evident in both light micrographs of celloidin-embedded material (Fig. 1) and electron micrographs of ultrathin sections (Fig. 2-5). Both show the same general anatomical features-rays, half-bordered pit-pairs, bordered pit-pairs on the radial walls of the tracheids (with the pits cut in various planes), and the irregularly thickened, generally unpitted tangential walls of the tracheids.

Wall layering very similar to that of living plants is observable in many electron micrographs (Fig. 2, 4, 5). The central electron-dense layer, markedly thickened at the corners of the cells, apparently represents a compound middle lamella. The primary walls and middle lamella appear indistinguishable, a phenomenon not uncommon in extant plants. The thin, electrontransparent band usually sandwiched between two electron-dense layers is the $\mathbf{S}_{1}$ layer of the secondary wall. The broad, frequently irregularly thickened, electron-dense layer internal to the $\mathrm{S}_{1}$ layer and next to the lumina of the cells is the $\mathrm{S}_{2}$ layer of the secondary wall. None of the sections appear to have an $\mathrm{S}_{3}$ layer of the secondary wall.

The $S_{3}$ layer in living plants may be lacking (sometimes in regular wood and usually in reaction wood), or frequently it is poorly developed (as in Picea, Alnus, and Fraxinus). Either the $\mathrm{S}_{3}$ layer was never present in this non-mineralized Callixylon wood or, more likely, it was entirely degraded, along with part of the $\mathrm{S}_{2}$ layer, prior to and during the fossilization process. Missing patches of wall, especially prominent on the tangential walls, and areas of reduced contrast (Fig. 2, 4, 5, and light micrograph Fig. 1) suggest that this wood might have undergone some decay since similar features are representative of walls of extant woods that have experienced decay and collapse through drying (W. A. Côté, Jr., personal communication, 1966; Cowling, 1965). The postulation of partial decay of the secondary wall in this wood is also consistent with the findings that the $S_{2}$ and $S_{3}$ layers of the secondary wall are less resistant to degradation than the primary wall and the $S_{1}$ layer of the secondary 


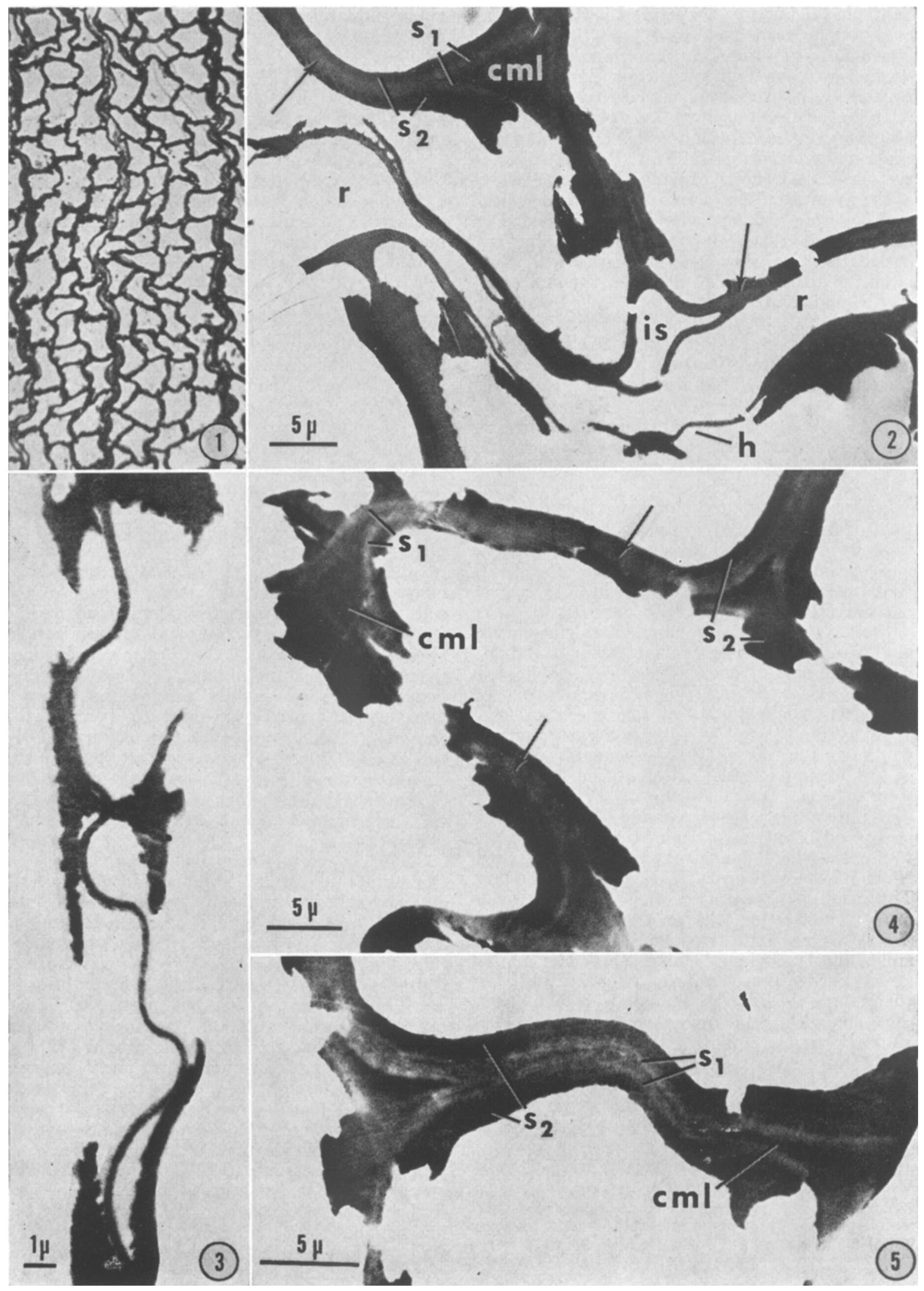


wall (Barghoorn and Scott, 1958; Mahmood, 1965).

In some electron micrographs the compound middle lamella does not seem to be present in the thinner parts of the walls, where instead two electron-transparent $S_{1}$ layers appear fused together in varying degrees (arrows, Fig. 2, 4). Uther micrographs show little or no layering in the walls (Fig. 3, parts of Fig. 2). Côté (personal communication, 1966) suggests that partial decay and gradual reduction in contrast might tend to mask the wall layering that is present.

Both bordered pit-pairs between tracheids (Fig. 3) and half-bordered pit-pairs between tracheids and ray parenchyma cells (Fig. 2) display prominent pit chambers, pit borders, pit apertures, and pit membranes. Tori, however, are absent from the pit membranes. Distortion of the wood during preservation presumably resulted in the convoluted appearance that nearly all pit membranes show in sectional view (Fig. 2, 3). Sections of bordered pit-pairs often miss the crossed slitlike pit apertures on either or both sides of the pit membranes with the result that pit chambers may appear completely enclosed.

Studies of surface replicas substantiate many of the above observations with the exception of the wall layering, and also reveal several other interesting details.

The main diagnostic feature of the wood of Callixylon is the radially aligned groups of circular bordered pits separated by prominent unpitted regions (Fig. 6). The alternately arranged pits, $10-18 \mu$ in diameter in this material of $C$. newberryi, are circular when not crowded, but more crowded pits assume an angular outline. The included pit apertures, which extend nearly to the margins of the pit borders, are narrow diagonal slits and are crossed in a pit-pair (Fig. $6,15)$. Figure 7 displays an electron micrograph of a replica of part of such a group of angular pits, all of which have their slitlike apertures oriented in the same direction. Surface views of pits (Fig. 8-11) show outlines of inner pit apertures or broken pit borders. Significantly, there is no evidence of tori in replicas of pit membranes (Fig. 12).

Since radially fractured surfaces of the silicified wood were replicated (Fig. 15), mineral being present in both the cell lumina and the pit cavities, electron micrographs of replicas show a variety of views of pits (Fig. 16). Fractures often occur only through tangential walls (line T, Fig. 15). Thus many replicas are not very useful since only tangential walls are seen, the radial walls with their pits being obscured by mineral of the cell lumina.

Breaks running along the inside (lumen) surfaces of the radial walls (lines A, B, Fig. 15) result in surface views of pits (Fig. 8-11, 16A, B). Fractures rumning directly along the lumen sides of the pit borders (line A, Fig. 15) reveal broad elliptical inner-pit apertures outlining the mineral of the pit cavities (Fig. 8, 16A), slight fracture damage to the pit borders perhaps having occurred as the specimen was split apart. Partial decay of the pit borders apparently is not very extensive in this unusually "well-preserved wood of Callixylon. More severe fracture damage to pit borders often occurs, however (line B, Fig. 15), the mineral of the pit chambers now being outlined by the fractured pit borders (Fig. 9, 11, 16B; Fig. 10, pits lower left, middle right, middle left, the fractures in this series occurring progressively closer to the pit membranes). In Fig. 11 the fracture wais very near the base of the pit border, only a small portion of this border remaining, so that merely a thin layer of mineral in the pit chamber conceals the pit membrane.

Views of complete pit membranes (Fig. 12, 16C), which frequently appear in a displaced position as seen in sectional view with both the light and the electron microscope, are sometimes observed when fractures occur along pit membranes (line C, Fig. 15). The circular band delimiting the pit membrane in Fig. 12 (long arrows; also Fig. 16C) represents the former attachment of the base of the pit border to the rest of the wall. The pit membrane in Fig. 12 apparently is displaced in a position toward the viewer, an outline of an aperture barely beingevident (short arrows, Fig. 12).

Fracturing along the entire inner surfaces of pit chambers (line E, Fig. 15) results in replicas of outer pit apertures and of pit-chamber (outer) surfaces of pit borders (Fig. 7, 16E). The edges of the pit borders, where the borders were attached to the rest of the wall, are represented by narrow circular bands (long arrows, Fig. 7; "b," Fig. 16E), which surface views of pits lack (Fig. 8-11, 16A, B). Fracturing along only part of the inner surfaces of the pit chambers (line D, Fig. 15) results in replicas of circular patches of

Fig. 1-5. Transverse sections of non-mineralized wood of Callixylon sp.: $\mathrm{cml}$,compound middle lamella; $h$, half-bordered pit-pair; is, intercellular space; $r, r a y ; S_{1}, S_{1}$ layer of secondary wall; $S_{2}, S_{2}$ layer of secondary wall. No $S_{3}$ layer is present. Missing patches of wall and areas of reduced contrast suggest partial decay of this wood , arrows indicate where wall layering seems obscured by decay.-Fig. 1. Light micrograph of celloidin-embedded material, $\times 175 .-$ Fig. 2-5. Electron micrographs of obliquely transverse ultrathin sections. - Fig. 2. Section through a ray, $\times 2300$. - Fig. 3 . Bordered pitpairs. The pit membranes lack tori, $\times 5300$.-Fig. 4 . Section showing layering in and decay of walls, $\times 2500 .-F i g .5$. Enlargement of upper right portion of Fig. 4 displaying wall layering, $\times 3400$. 


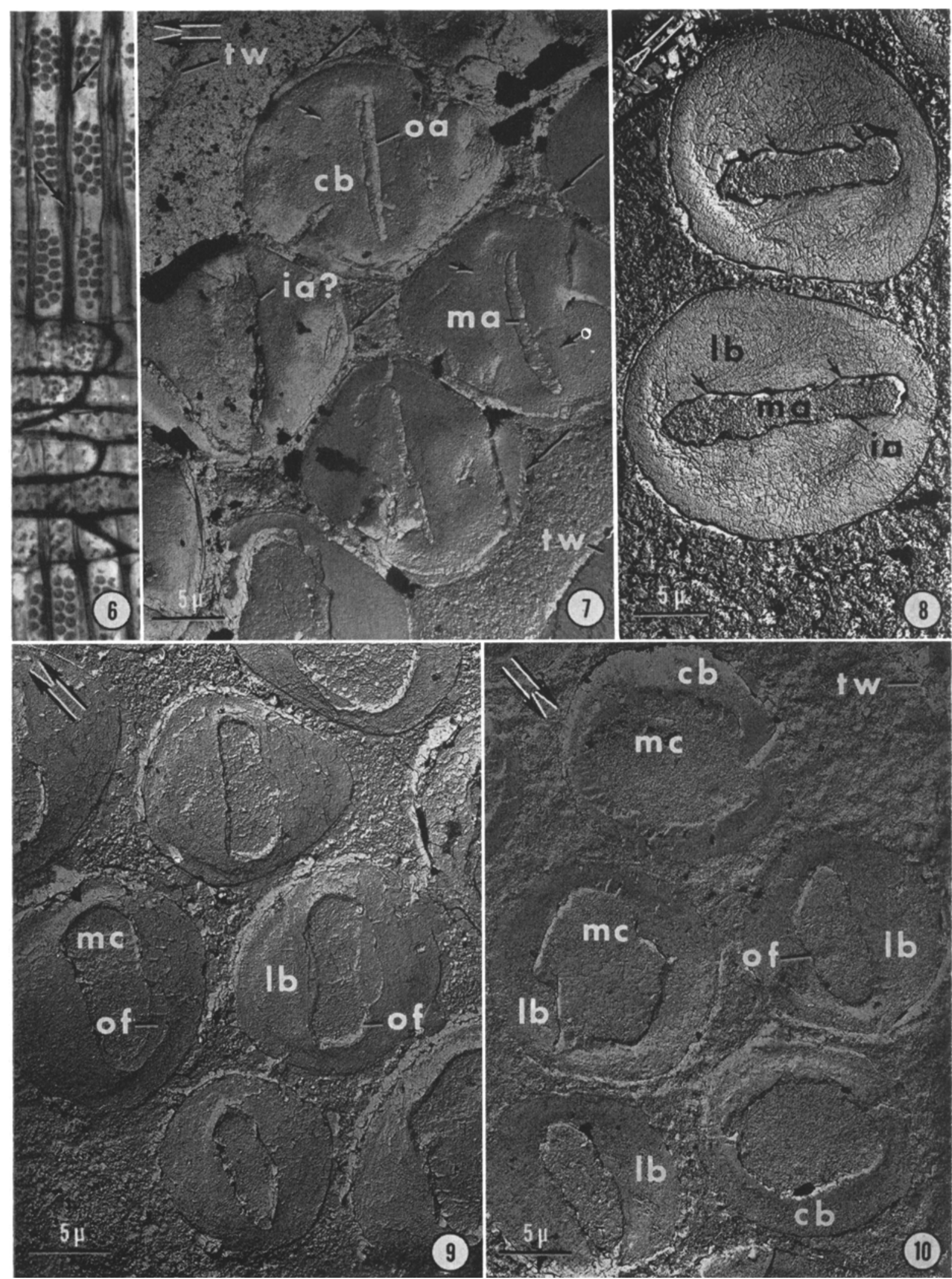


mineral of the pit chambers concealing the pit apertures and portions of the pit borders (Fig. 10, pits labelled "cb"; Fig. 16D).

Figure 15 is a diagrammatic representation of the bordered pit-pairs of Callixylon. The outer apertures of the pit canals are considerably narrower but only slightly shorter than the inner apertures (Fig. 15, 16A, D, E). Pit apertures in replicas of pit-chamber surfaces of pit borders appear as narrow slits (Fig. 7, 16E), whereas apertures in replicas of lumen surfaces of pit borders appear larger and elliptical (Fig. 8, 16B). The narrow slits in Fig. 7 represent the outer pit apertures, but around these can be seen indications of the larger inner pit apertures (short arrows, Fig. 7). Replicas also show parts of the pit canals narrowing toward the pit chambers (arrows, Fig. 8). The pit borders of Callixylon apparently do not protrude very much into the cell lumina (Fig, 2, 3, 15). Detailed light microscopic examination of transverse and longitudinal sections of both the non-mineralized wood of Callixylon (monitor slides of epon-embedded material and slides of celloidin-embedded material) and the silicified wood of $C$. newberryi (slides of ground thin sections kindly loaned by Professors Arnold and Beck) substantiate the size difference of the inner- and outer-pit apertures, hitherto unreported, as well as the more obvious lack of significant protrusion of pits into the cell lumina.

Replicas were also prepared of the prominent unpitted areas between the groups of bordered pits of Callixylon, but crassulae, thickenings reported from light microscopic studies (Arnold, 1929, 1931; also Fig. 6), could not be detected in the unpitted regions by electron microscopy of either replicas or sections.

Fibrillar structure and organization in fossilized wood have been studied by light microscopy, darkfield microscopy, polarization optics, electron microscopy, X-ray diffraction, and other methods (Sen, 1963). Eicke (1952, 1954, 1957), for example, observed microfibrils 200-300 A wide in her silicified Glyptostroboxylon material. Microfibrillar structure, however, is not very discernible in either sections or replicas of Callixylon wood. High-magnification electron micrographs of sections of cell walls occasionally show striations, but these seem to be artifacts resulting from sectioning. Replicas of pit membranes display a very homogeneous structure (Fig. 12) and do not exhibit the radial arrangement of microfibrils so typical of the pit membranes of extant conifers. Replicas of other areas of the walls also reveal essentially no submicroscopic structure.

Cordaitean secondary wood resembles that of Callixylon in having alternately arranged circular bordered pits with narrow, diagonal pit apertures. Electron micrographs of replicas of Cordaites wood are similar to those of Callixylon wood (compare Fig. 13, 14 with Fig. 9-11, especially Fig. 14 with Fig. 12). Tori are absent from the pit membranes of Cordaites, and mircofibrillar structure is obscure. Fracture damage to and possibly also decay of the pit borders of this calcified, rather poorly preserved material apparently occurred (Fig. 13, 14). The pit membrane at the lower right of Fig. 14 has a homogeneous structure comparable to that of Callixylon (Fig. 12). Other pit membranes (Fig. 14, upper row and left center) superficially appear to have tori; actually the pit membranes are appressed against the pit borders of the adjacent cell, the outlines of the pit borders and the mineral in the pit chambers of the adjacent cell having produced the effect of a torus. A fractured, possibly decayed pit border and the mineral of its pit chamber are evident in the right center of Fig. 14. Part of the pit border and part of the mineral in the pit chamber of the pit in the lower left of Fig. 14 broke away to reveal a portion of the pit membrane.

Discussion-Bordered pits become rather common only by the Upper Devonian, and tori are phylogenetically much more recent structures. In view of the great age of Callixylon (Upper Devonian and Lower Mississippian) and Cordaites (mainly Pennsylvanian), it is not surprising that tori are absent from the pit membranes of these plants. Thomson (1914) was unable to detect a torus in any cordaitean wood and concluded that the structure is absent in the Cordaitales (see also Holden, 1915). From the functional standpoint it seems unlikely that tori would be found in pit-pairs such as those of Callixylon that have pronounced slitlike, elongate outer apertures. Holden (1917), in fact, stated

Fig. 6-10. Radial views of silicified wood of Callixylon newberryi.-Fig. 6. Light micrograph showing crassulae (arrows) and characteristic grouping of bordered pits, $\times 200$. Photograph by C. B. Beck.-Fig. 7-10. Electron micrographs of replicas: $c b$, pit-chamber side of pit border; ia, inner pit aperture; lb, lumen side of pit border; ma, mineral of pit canal; mc, mineral of pit chamber; oa, outer pit aperture; of, outline of fractured pit border; tw, tangential cell wall. Double arrows in upper left corners of micrographs indicate direction of chromium shadowing; light areas show very little detail because of absence of chromium due to shielding from metal by adjacent surface projections.-Fig. 7 . View of outer pit apertures (narrow slits) and pit-chamber surfaces of pit borders. Long arrows indicate where pit borders were attached to rest of wall; short arrows show indications of the larger inner pit apertures, $\times 2400 .-$ Fig. 8 . View of pits showing inner pit apertures and lumen surfaces of pit borders; arrows indicate pit canals tapering toward pit chambers, $\times 2500 .-$ Fig. 9, 10. Surface views of pits exhibiting severe fracture damage to pit borders of pits labelled "lb." In Fig. 10 mineral of pit chambers of pits labelled "cb" obscures outer pit apertures and parts of the pit borders. Fig. $9, \times 2700 ;$ Fig. $10, \times 2400$. 

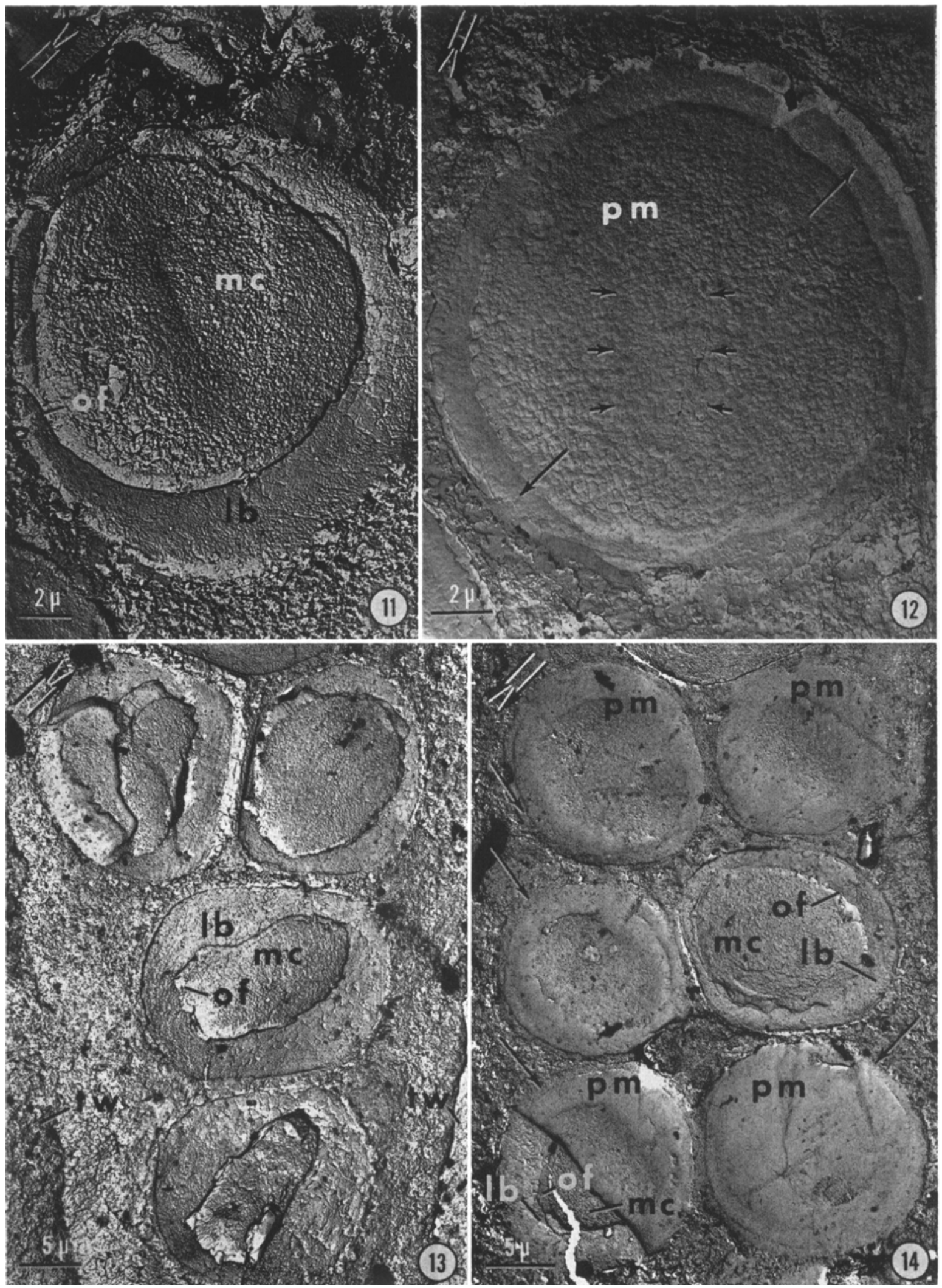
that there probably were no tori in any Paleozoic woods.

Tori, however, have been reported in Jurassic woods such as Metacedroxylon scoticum (Holden, 1915) and Protopiceoxylon wordii (Walton, 1927); in Cretaceous woods such as Paracedroxylon scituatense (Sinnott, 1909), Cedroxylon disjunctum (Bannan and Fry, 1957), Cedrus alaskensis (Arnold, 1952), Piceoxylon christopheri and $P$. thomsoni (Bannan and Fry, 1957), Pinoxylon dacotense (Bailey, 1933), and Pityoxylon and Araucariopitys (Thomson, 1914); in Tertiary woods such as Glyptostroboxylon (Eicke, 1952, 1953, 1954, 1957), Cedroxylon greenlandicum (Walton, 1927), and the Miocene Cedrus penhallowii (Barghoorn and Bailey, 1938); and very likely in other fossil woods as well, although a perusal of the paleobotanical literature has yielded only the cases noted. No mention of the occurrence of tori in pre-Jurassic plants could be found in the literature. Since the main coniferous families were well established by the Cretaceous, one would expect to find tori in Jurassic and more recent woods. The pre-Jurassic torus, however, still remains an enigma. The wood of several other pre-Jurassic plants, including Lyginopteris, Medullosa, Dadoxylon, and other species of Callixylon, was also investigated with the electron microscope with the faint hope that something could be determined about the phylogeny of tori. But all investigations of these fossil plants thus far have been unfruitful, and any remarks about the evolution of tori must be based largely on data from living plants.

Eicke (1963) postulated that a homogeneous type of pit membrane like that of Cycas (a tight membrane of many fine microfibrils interwoven in a dispersed pattern, but lacking openings and a torus as in the pit membranes of hardwoods, according to Liese, 1965) represents a primitive condition among gymnosperms from which structurally more complex pit membranes and tori were derived. The well-known pit membrane structure of the Pinaceae is very specialized (the pit membrane consisting of a distinct torus and a margo of moderately dense radially oriented microfibrils separated by large openings) and is not representative of the gymnosperms as a whole, most gymnospermous genera, in fact, lacking tori (Liese, 1965). Krahmer and Côté (1963), in line with Eicke's (1958) observations on the Araucariaceae, noted that families or species possessing a pit membrane like that of Thuja plicata (torus absent, the pit membrane with small openings and with numerous, closely packed, radiating microfibrillar strands) are considered to hold an intermediate position in the phylogeny of pit membranes of the conifers. It thus seems likely that tori evolved along the following lines: cycad-type of pit membrane to thujoid-type of pit membrane to pinoid-type of pit membrane. This series should not be construed, however, as a direct evolutionary line with implied relationships among the members.

A distinct torus and margo probably evolved by orientation and aggregation of microfibrils into a radial pattern followed by development of openings in the pit membrane and finally by apposition of microfibrils into a central thickening, the torus. There seems to be a close agreement between this postulated phylogeny of the torus and the ontogeny of the torus (Eicke, 1958), since the torus is also the last structure to be formed during the development of bordered pit-pairs of tracheids (Frey-Wyssling, Bosshard, and Mühlethaler, 1956).

The present study of the pit ultrastructure of Callixylon and Cordaites offers some evidence in support of the hypothesis (Eicke, 1963) that the cycad-type of pit membrane represents a primitive condition among gymnosperms. Callixylon has been postulated as representing a progymnosperm, an assemblage of plants considered ancestral to both the cycadophytes and the coniferophytes (Beck, 1960). Florin (1951) has shown that the cordaites are closely related, and probably ancestral, to the conifers. The pit membranes of Callixylon and Cordaites, which are quite homogeneous in structure and which lack openings or tori (Fig. 12, 14), might, therefore, represent a primitive condition analogous to the cycad-type of pit membrane, from which structurally more complex pit membranes and tori evolved. It is a moot point whether the homogeneous structure apparent in the pit membranes of Callixylon and Cordaites is actually the real condition or whether it is due to faulty preservation, but the age of these plants and their presumed relationships at least do not militate against the idea that this type of pit membrane (Fig. 12, 14) represents a possible primitive form.

The fine structure of the wall of Callixylon is remarkably preserved and corresponds very closely to that in living plants. Previous studies of

Fig. 11-14. Electron micrographs of replicas of radial surfaces of wood of Callixylon newberryi and Cordaites sp.: lb, lumen side of pit border; mc, mineral of pit chamber; of, outline of fractured pit border; pm, pit membrane; tw, tangential cell wall. Double arrows indicate direction of chromium shadowing; long single arrows indicate where pit borders were attached to rest of wall.-Fig. 11. View of pit of Callixylon showing very severe fracture damage to pit border, $\times 4300$. - Fig. 12. View of pit membrane of Callixylon displaying its homogeneous structure and lack of a torus; short arrows indicate outline of a pit aperture, $\times 5000 .-F i g .13$. Surface view of bordered pits of Cordaites (compare with Fig. 9-11); fracture damage to pit borders severe, $\times 2100$.- Fig. 14. View of pit membranes of Cordaites showing their homogeneous structure and lack of tori (compare with Fig. 12). Fractured pit borders are evident at lower left and right center, $\times 2300$. 

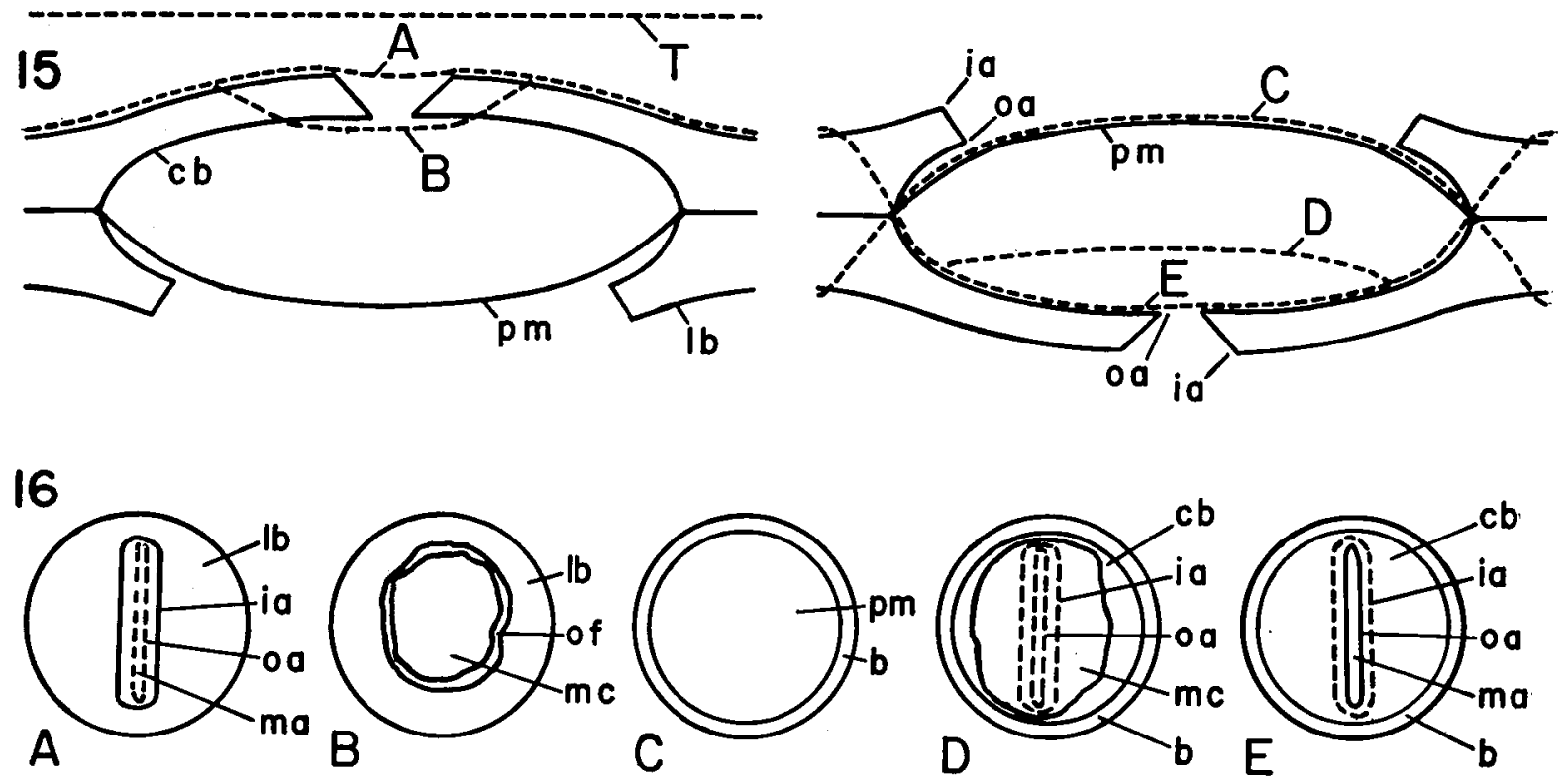

Fig. 15, 16. Diagrammatic representation of structure and radial fracturing of bordered pit-pairs of Callixylon wood: $\mathrm{b}$, area where base of pit border was attached to rest of wall; $\mathrm{cb}$, pit-chamber side of pit border; ia, inner-pit aperture; $\mathrm{lb}$, lumen side of pit border; ma, mineral of pit canal ; mc, mineral of pit chamber; oa, outer-pit aperture; of, outline of fractured pit border; pm, pit membrane.-Fig. 15. Sectional views of pit-pairs with various planes of fracturing indicated (dashed lines A-E, T). - Fig. 16. Radial face views $(\mathrm{A}-\mathrm{E})$ of pits that would result from replicas of areas of wall below fractures (dashed lines $A-E$ ) of Fig. 15. Dashed outlines indicate structures not seen and lying immediately below fractured surfaces. A, inner pit aperture and lumen side of pit border (compare with Fig. 8); B, pit border broken by fracturing (compare with Fig. 9, 11; Fig. 10, pits labelled "lb"); C, pit membrane (compare with Fig. 12); D, mineral of pit chamber obscuring outer pit aperture and part of pit border (compare with Fig. 10, pits labelled "cb"); E. outer pit aperture and pit-chamber side of pit border (compare with Fig. 7).

the fine structure of fossilized wood have demonstrated that there is little difference between the general pattern of arrangement of submicroscopic units in recent and extinct wood (Eicke, 1952, 1954, 1957; Purelis, 1962; Sen, 1963). The present study shows that there is not much difference between the general pattern of wall layering in extant and fossilized wood. Although many extinct plants exhibit habits, tissue patterns, and reproductive structures quite different from those of modern plants, their wood ultrastructure seems very much like that of extant plants. The basic organization of the cell wall probably evolved early in the history of the land flora and apparently has not changed significantly since Devonian times.

\section{LITERATURE CITED}

Annold, C. A. 1929. On the radial pitting in Callixylon. Amer. J. Bot. 16: 391-393.

1931. On Callixylon newberryi (Dawson) Elkins et Wieland. Contrib. Mus. Paleontol. Univ. Michigan 3: $207-232$.

- 1952. Silicified plant remains from the Mesozoic and Tertiary of western North America. II. Some fossil woods from Northern Alaska. Papers Michigan Acad. Sci., Arts, Letters 38: 9-20.

BaILEx, I. W. 1933. The cambium and its derivative tissues. VII. Problems in identifying the wood of Mesozoic Coniferae. Ann. Bot. 47: 145-157.

Bannan, M. W., and W. L. Fry. 1957. Three Cretaceous woods from the Canadian Aretic. Can. J. Bot. 35: $327-337$.

Barghoorn, E. S., AND I. W. BaIleyy. 1938. The occurrence of Cedrus in the auriferous gravels of California. Amer. J. Bot. 25: 641-647.

-, AND J. W. Schopf. 1966. Microorganisms three billion years old from the Precambrian of South Africa. Science 152: 758-763.

——, AND R. A. ScotT. 1958. Degradation of the plant cell wall and its relation to certain tracheary features of the Lepidodendrales. Amer. J. Bot. 45: $222-227$.

Barton, H. M., AND D. J. Jones. 1948. Electron microfossils. Science 108: 745-746.

Beals, T. F., and W. C. Brgelow. 1962. A technique for removing plastic backing films in the preparation of electron microscope specimens, p. 155-159. In Symposium on advances in electron metallography and electron-probe microanalysis, ASTM Spec. Tech. Pub. No. 317. American Society for Testing and Materials, Philadelphia.

Beck, C. B. 1960. The identity of Archaeopteris and Callixylon. Brittonia 12: 351-368.

Cốté, W. A., Jr., Z. Koran, and A. C. Day. 1964. Replica techniques for electron microscopy of wood and paper. Tappi 47: 477-484.

Cowling, E. B. 1965. Mieroorganisms and microbial enzyme systems as selective tools in wood anatomy, 
p. 341-368. In W. A. Côté, Jr. [ed.], Cellular ultrastructure of woody plants. Syracuse Univ. Press, Syracuse, N. Y.

Ehrlich, H. G., and J. W. Hall. 1959. The ultrastructure of Eocene pollen. Grana Palynol. 2: 32-35.

Eicke, R. 1952. Neues über die Feinstruktur der Zellwand verkieselter Hölzer. Ber. Deut. Bot. Ges. 65: $246-248$.

. 1953. Was können elektronenmikroskopische Bilder über den Vorgang der Verkieselung fossiler Hölzer aussagen? Z. Wiss. Mikroskop. Tech. 61: 302305.

. 1954. Elektronenmikroskopische Untersuchungen an verkieselen Coniferen. Palaeontographica 97B: $36-46$.

- 1957. Elektronenmikroskopische Untersuchungen an Gymnospermenhölzern als Beitrag zur Phylogenie der Gnetales. Bot. Jahrb. 77: 193-217.

- 1958. Beitrag zur Kenntnis der submikroskopischen Struktur der Araucariaceenhölzer. Ber. Deut. Bot. Ges. 71: 231-240.

- 1963. Feinbauuntersuchungen an den Tracheiden von Cycadeen II. Cycas media und Cycas pectinata. Ber. Deut. Bot. Ges. 76: 229-234.

FI,orin, R. 1951. Evolution in cordaites and conifers. Acta Horti Bergiani 15: 285-388.

Frey-Wyssling, A., H. H. Bosshard, and K. MühleTHALER. 1956. Die submikroskopische Entwicklung der Hoftüpfel. Planta 47: 115-126.

FRY, W. L. 1954. A study of the Carboniferous lycopod, Paurodendron, gen. nov. Amer. J. Bot. 41: 415-428.

Holuen, R. 1915. A Jurassic wood from Scotland. New Phytol. 14: 205-209.

- 1917. On the anatomy of two Palaeozoic stems from India. Ann. Bot. 31: 315-326.

Jux, U., AND V. MoERICKE. 1965. Tylthodiscus suevicus Eisenack eine Thekamöbe? Palaeontographica 115B: 107-116.

Krahmer, R. L., ANd W. A. Cốté, JR. 1963. Changes in coniferous wood cells associated with heartwood formation. Tappi 46: 42-49.

LiESE, W. 1965. The fine structure of bordered pits in softwoods, p. 271-290. In W. A. Côté, Jr. [ed.], Cellular ultrastructure of woody plants. Syracuse Univ. Press, Syracuse, N. Y.

McCartney, J. T., R. E. Walline, and S. Ergun. 1961. Preparation of ultrathin sections of coal. U. S. Bur. Mines Rep. Invest. 5885: 1-5.

Mahmood, A. 1965. Secondary walls in phloem of Pinus radiata D. Don. Nature 207: 657-658.

Petcits, J. M. 1966. Exine structure in some fossil and recent spores and pollen as revealed by light and electron microscopy. Bull. Brit. Mus. (Nat. Hist.) Geol. 13: 221-257.

structure of the Mesozoic pollen Classopollis. Pollen et Spores 6: 611-620.

Preston, G. D., And F. W. Cuckow. 1944. Electronmicrographs of coal, p. 334-335. In Conference on the ultra-fine structure of coals \& cokes. Proceedings ... held at the Royal Institution, London, June 24 and 25, 1943. British Coal Utilization Research Association, London.

Purelis, G. A. 1962. Microstructure of fossil plant cell walls. Amer. J. Bot. 49:663 (Abstr.)

SAss, J. E. 1958. Botanical microtechnique. 3rd ed. Iowa State College Press, Ames.

Sen, J. 1963. Fine structure in degraded, ancient and buried wood, and in other fossilized plant derivatives. II. Bot. Rev, 29: 230-242.

Sinnotr, E. W. 1909. Paracedroxylon, a new type of Araucarian wood. Rhodora 11: 165-173.

Tromson, R. B. 1914. On the comparative anatomy and affinities of the Araucarineae. Phil. Trans. Roy. Soc. London 204B: 1-50.

Whlton, J. 1927. On some fossil woods of Mesozoic and Tertiary age from the Arctic zone. Ann. Bot. 41: 239252.

Wesley, A., AND B. Kuyper. 1951. Electron-microscopic observations on the xylem elements of a fossil plant. Nature 168: 137-140.

Wilson, L. R., AND A. W. Johnston. 1940. A new species of Cordaites from the Pennsylvanian strata of Iowa. Bull. Torrev Bot. Club 67: 117-120. 